\title{
EFFECT OF CONTRACEPTIVE USE, PARITY, AND SOCIAL ECONOMIC FACTORS ON AGE AT MENOPAUSE AT BENDO COMMUNITY HEALTH CENTER, KEDIRI, EAST JAVA
}

\author{
Estin Gita Maringga' ${ }^{1)}$ Rita Benya Adriani²), Ambar Mudigdo3) \\ 1)Masters Program in Public Health, Sebelas Maret University \\ 2)School of Health Polytechnics, Surakarta \\ 3)Department of Anatomical Pathology, Faculty of Medicine, Sebelas Maret \\ University
}

\begin{abstract}
Background: Menopause is the natural cessation of menstruation that usually occurs between the ages of 45 and 55. Menopause women may experience some undesirable effects, such as sleep disturbance, prone to pain, increased susceptibility to sexually transmitted disease (STD), and thinner hair. It is hypothesized that age at menopause is affected by genetic factor, as well as psychosocial factors. This study aimed to the effect of contraceptive use, parity, and social economic factors on age at menopause.

Subjects and Method: This study was an analytic observatioanal study using case control design. The study was conducted in Bendo Village, Bendo Village, Sumberbendo Village, Pelem Village, Darungan Village, and Sambirejo Village in Community Health Center Bendo, Kediri, East Java, from 8-31 March 2017. A sample of 120 menopausal women was selected for this study by fixed disease sampling. The dependent variable was age at menopause. The independent variables were hormonal contraceptive use, duration of contraceptive use, parity, education level, and family income. The data were collected by questionnaire, and analyzed by path analysis.

Results: Menopausal age was affected by duration of hormonal contraceptive use $(b=0.29 ; \mathrm{SE}=0.12 ; \mathrm{p}=0.014)$, parity $(b=1.98 ; \mathrm{SE}=0.49 ; \mathrm{p}=0.001)$, and family income $(b=2.29 ; \mathrm{SE}=0.88 ; \mathrm{p}=0.009)$. Duration of hormonal contraceptive use was affected by hormonal contraceptive use $(b=5.23 ; \mathrm{SE}=$ $0.57 ; p=0.001)$ and parity $(b=1.22 ; S E=0.27 ; p=0.001)$. Family income was affected by parity $(b=0.14 ; \mathrm{SE}=0.05 ; \mathrm{p}=0.002)$ and education level $(\mathrm{b}=0.10$; $\mathrm{SE}=0.11 ; \mathrm{p}=0.361)$.

Conclusion: Menopausal age is directly affected by duration of hormonal contraceptive use, parity, and family income. Menopausal age is indirectly affected by hormonal contraceptive use, parity, and education level.
\end{abstract}

Keywords: menopausal age, hormonal contraceptive, parity, social economic factors, path analysis

Correspondence: Estin Gita Maringga. Masters Program in Public Health, Sebelas Maret University, Jl. Ir. Sutami 36 A, Surakarta 57126, Central Java, Indonesia. Email: estin.gita@gmail.com. Mobile: +6281357673430. 